\title{
PGMs: A cornucopia of possible applications
}

\author{
by L.A. Cornish
}

\section{Synopsis}

South Africa has been mining PGMs for many years and has a vested interest in the usefulness of these metals, although originally, there was little thought about downstream beneficiation and some of the products were later purchased, in effect repurchasing the raw materials. However, for about 20 years, it has been realised that in order to build wealth sustainably, at least some of the beneficiation and development has to be done in South Africa. This is because for each stage of beneficiation, the value of the commodity increases and so to buy the PGMs back in a later state is uneconomical. Also, the industries need to be established here in South Africa, so that South Africans can work in them and become part of the workforce and generate their own wealth and sustainability for their families. This is part of the rationale of the AMI.

In order to drive this, as well as a viable commercial strategy, with viable and wanted products, there has to be something different in the production mixture, for example, the product has to be better, new or cheaper. This is where research is used to try and develop new capabilities, or to improve them.

Keywords

PGMs, application, product development. in the production mixture. For example, the product has to be novel, better, or cheaper than what is available elsewhere. This is where research is used to try and develop new capabilities, or to improve them, or to develop better production routes and methods. Thus the research is important, although it must be remembered that while 'blue skies' research can lead to useful developments, the aim of the AMI is to remain focused on building local industry, so the research must have a perceived and needed impact.

Figure 1 shows some of the applications for which PGMs have been used over the years, some being very long-standing, together with some of the areas that have been researched. Thus, this diagram represents a partial overview of some older applications, as well as some later developments. There is a wide variety of properties and products and it is the basis for a discussion of past projects and the identification of future research areas that could lead to new industries.

\section{Different applications for PGMs}

South Africa has been mining PGMs for many years and has been the leading supplier of PGMs because of the richness of the Bushveld Complex. Originally, there was little thought about downstream beneficiation, with more emphasis being placed on exporting the metals. Some of the products were later purchased, which is uneconomical, because for each stage of beneficiation, the value of the commodity increases. However, for about 20 years, it has been realised that in order to build wealth sustainably, South Africa must have a vested interest in the usefulness of these metals and that at least some of the beneficiation and development has to be done in locally. Also, the industries need to be established here in South African order to create emploment oportunities, so that South Africans can generate their own wealth and sustainability for their families. This is part of the rationale of the Advanced Metals Initiative (AMI).

In order to drive this, as well as a viable commercial strategy, with viable and wanted products, there has to be something different

\section{Glass industry}

Platinum-based alloys possess high melting points, good thermal stability and thermal shock resistance and good corrosion and oxidation resistance and different approaches to strengthening. The alloys were established by the 1980s (Hammer and Kaufmann, 1982; Heywood, 1988; Heraeus, 2011). There are several applications where the high electrical

* DST-NRF Centre of Excellence in Strong Materials, hosted by University of the Witwatersrand, Johannesburg and School of Chemical and Metallurgical Engineering, University of the Witwatersrand, South Africa.

(c) The Southern African Institute of Mining and Metallurgy, 2017. ISSN 2225-6253. This paper was first presented at the AMI Precious Metals 2017 Conference 'The Precious Metals Development Network' 17-20 October 2017, Protea Hotel Ranch Resort, Polokwane, South Africa. 


\section{PGMs: A cornucopia of possible applications}

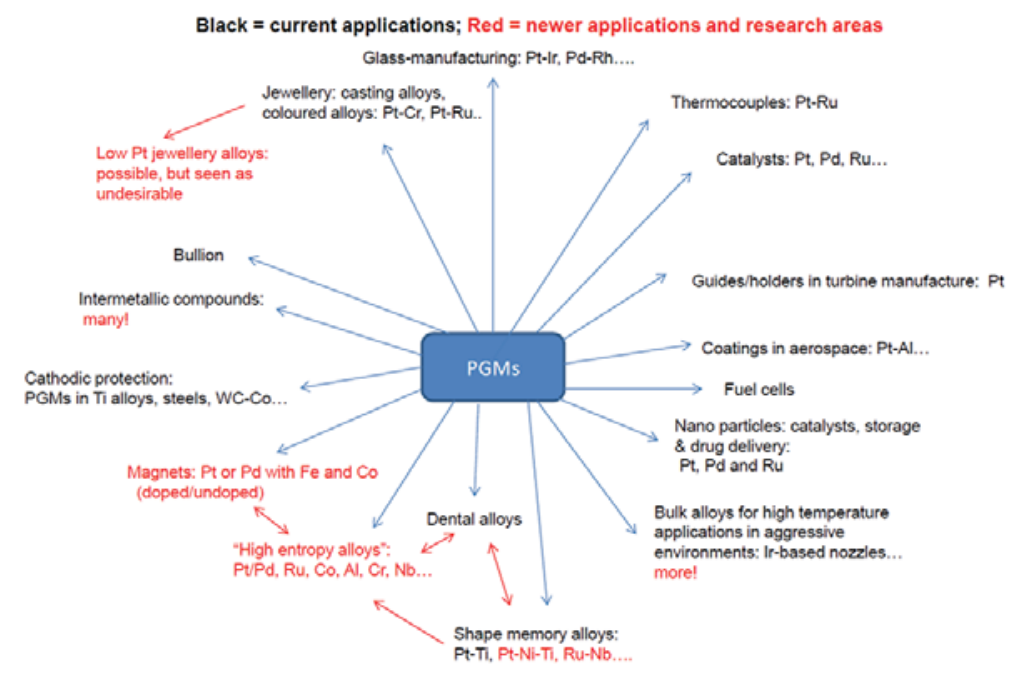

Figure 1-Some areas of applications and research in PGMs

and thermal conductivity of Pt are important (Fischer, 1992). Mechanically, Pt alloyed with rhodium or iridium combine high ductility with adequate creep strength and these properties give the alloys potential for applications in the chemical, space technology and glass industries (Fischer, 2001; Whalen, 1988; Lupton, 1990). In the spacecraft industry, PGMs are used to increase the heat resistance of rocket engine nozzles. A very important application is the manufacture of high-purity optical glasses and glass fibres by using platinum-containing tank furnaces, stirrers and feeders to withstand the high temperatures, mechanical loads and corrosive attack under the glass manufacturing and shaping conditions. In glasses, outstanding purity, homogeneity and the absence of bubble inclusions can be achieved only by using platinum alloys. If ceramic melting vessels were used, ceramic particles would be loosened by erosion, which would contaminate the glass melts and so compromise the desired optical properties such as transmittance. The alloys are expensive, but there are very few other materials that could replace platinum without risk of compromising the product. Thus, this is a valuable and safe use for platinum and some of its alloys.

\section{Thermocouples}

Another 'standard use' of PGMs is in thermocouples and this arises because of their high electrical and thermal conductivity, as well as stability due to their high corrosion resistance. Typical alloys are $\mathrm{Pt}-\mathrm{Rh}$ and $\mathrm{Pt}-\mathrm{Ru}$. The thermocouples do eventually degrade in aggressive environments and become brittle, but usually without much impairment of the electrical and conductive properties.

\section{Catalysts}

A long-standing use of PGMs is in catalysts and South Africa has established an autocatalyst manufacturing and refurbishment plant for automobiles. The alloys work very well and can be based on Pt or Pd, but are expensive. Competitors would like to replace these expensive alloys with something cheaper, but so far, nothing has been found that matches the good catalytic properties and robustness of the PGMs. There is also added flexibility because of work done with nanoparticles, which has the potential to increase the effectiveness of the catalysts, as the surface areas are increased. Much work has been done in South Africa on catalysts for different applications, both for PGMs, as well as for gold under the Autek project administered by Mintek. However, there is always a challenge with catalysis, because competitors are always looking for cheaper catalysts and there is a risk that the cheapness of other catalysts will offset the greater effectiveness of the PGM catalysts.

The knowledge that palladium could be a ductile permeable storage medium for hydrogen dates from the 1970s (Knapton, 1977) and there is still work being done to optimise the properties, although it is used in hydrogen fuel cells.

\section{Jewellery}

Platinum has been used for jewellery for many years. Most of the alloys are $95 \mathrm{wt} \% \mathrm{Pt}$, with the other components usually being added to improve the hardness, since platinum is relatively soft. Various methods of surface hardening have been tried (Weber et al., 1996; McGill and Lucas, 1987). Other additions have been made to improve the flowability and hence castability. The most common alloying elements are copper, palladium, cobalt, gallium, iridium, ruthenium and indium. Copper is commonly added to make a generalpurpose alloy which casts well and is easy to work, and titanium has also been identified as a possible addition (Biggs et al., 2005). There is a 950 (95 wt\%) hallmark for platinum alloys, which means that only $5 \mathrm{wt} \%$ is available for any additions. This hallmark is also synonymous with 'quality' and closely guarded by the platinum industry. This situation is different from gold, where there are hallmarks for a wide range of alloys and gold contents. This means that there is much less flexibility in the platinum jewellery alloys, because they have to be $95 \mathrm{wt} \% \mathrm{Pt}$ to be considered for hallmarking.

Under the Innovation Fund, the Hot Platinum project was established. The aim was two-fold: to develop casting alloys for jewellery applications and also to develop small furnaces suitable for jewellers to use. Although some alloys were successfully developed, it was the furnaces that became more 
successful and these are still being sold under the Hot Platinum brand, in large and small sizes. This is an example of a successful project.

\section{Cathodic protection}

In 1911, Monnartz (1911) found that the corrosion of ironchromium alloys was much reduced by wrapping platinum wire about the samples, or by alloying with platinum. Subsequently, researchers added PGMs to various alloys to improve the corrosion resistance: Stern and Wissenberg (1959) added palladium to titanium; Tomashov (1958, 1967, 1970) added palladium to steels; Greene (1961) worked on chromium and high-chromium nickel-chromium alloys in sulphuric acids; Biefer (1970) added PGMs to type 430 stainless steel (and found $\mathrm{Ru}$ performed better than $\mathrm{Pd}$ ); Tomashov (1976) added ruthenium to titanium and titanium-nickel alloys; Streicher (1977) added PGMs to stainless steels. Hoar (1960) identified platinum, palladium, rhodium and ruthenium as the best PGMs for cathodic medication, but as platinum and rhodium are expensive, ruthenium is likely to be the PGM of choice in South Africa. Green et al. (1961) gave a ranking of iridium, rhodium, ruthenium, platinum and palladium being more effective than osmium, gold or rhenium in maintaining a stable passivity. Although the ranking is not always obeyed, a discernable ranking of the alloying elements for improving corrosion is: Ir $>\mathrm{Rh}>\mathrm{Ru}>\mathrm{Pt}>\mathrm{Pd}>\mathrm{Os}>\mathrm{Au}>\mathrm{Re}$, by comparing the corrosion rates and this was used by Potgieter $(1990,1991)$ in his discussion of the cathododic modification effect of the PGMs. Tomashov (1980) also looked at additions of 0.1 to $0.4 \mathrm{wt} \% \mathrm{Ru}, \mathrm{Os}$, Ir, Pt or Pd and Chernova (1980) studied 0.2-0.4 wt\% Ru. Tomashov et al. (1984) reported that $\mathrm{Ru}$ could block lattice defects, as well as enhancing the corrosion resistance in steels. Tomashov et al. (1969) added 0.1-0.4 wt $\%$ osmium, iridium and ruthenium to chromium alloys and found that the rate of dissolution in chromium-ruthenium alloys in the active state decreased with increasing $\mathrm{Ru}$ content. Tomashov et al. (1976) found that $0.2 \%$ Ru addition improved the corrosion resistance of Ti-Ni alloys. Streicher (1977) found that Ru additions of $0.2 \mathrm{wt} \%$ conferred better corrosion resistance than the same amount of $\mathrm{Pd}$. More recently, work in this area has increased, for example, Zhang. (2009) and Olaseinde et al. (2012), Potgieter (1995), to explain the effect, Van der Lingen and Sandenbergh (2001), and there is also work on ion implantation of PGMs in an attempt to retard stress corrosion cracking. Shing et al. (2001) added ruthenium to WC-Co alloys as a strengthener, with improved results and this also has potential for improving the corrosion resistance.

\section{Bulk alloys for potential application for turbines and the aerospace industry}

Nickel-based superalloys (NBSAs) have excellent mechanical properties due to precipitation strengthening of small, stable, ordered particles and have long been the 'standard' for aerospace alloys, although now lighter titanium alloys are being targeted for some of the components at lower temperatures. Platinum has similar chemistry to nickel and so reacts similarly with the alloying elements and has been investigated as a potential substitute in higher temperature alloys in even more aggressive environments (Coupland et al., 1980; Fischer et al., 1997, 1999a, 1999b, 2001; Völkl et al., 2000; Wolff and Hill, 2000). The potential of using an fcc PGM analogue was mooted several times (Bard et al., 1994), in NIMS, Japan owing to the good properties of iridium-based and rhodium-based alloys (Yamabe et al., 1996, 1997, 1998a, 1998b, 1999; Yu et al., 2000), Pt-Ir alloys (YamabeMiterai et al., 2003), Pt-Al-Nb and Pt-Al-Ir-Nb alloys (Huang et al., 2004) and platinum-based alloys in South Africa (Wolff and Hill, 2000). The PGMs and nickel have similar structures (mostly fcc) and similar chemistries for the formation of similar phases. Advantages of PGM-based alloys over the NBSAs are the increased melting temperatures (e.g. $2443^{\circ} \mathrm{C}$ for iridium, $1769^{\circ} \mathrm{C}$ for platinum compared to $1455^{\circ} \mathrm{C}$ for nickel) and the excellent corrosion properties. Although platinum-based alloys would have been unlikely to replace all NBSAs on account of their higher price and higher density (Pt has a density of 21.5 g.cm-3, compared to nickel's density of $8.9 \mathrm{~g} . \mathrm{cm}^{-3}$ ), they were identified as having potential for use in components subjected to the highest temperatures. For Pt-based alloys, an increase in application temperature of at least $200^{\circ} \mathrm{C}$ could be gained (and more for Ir-based alloys). Although changes in engine design could be necessary, the higher application temperatures could offset the increased density and expense and the alloys could be recycled.

Most PGMs have the face-centred cubic (fcc) structure, apart from ruthenium, which is hexagonal close-packed (hcp or $\mathrm{cph}$ ). Iridium has a higher melting point than platinum, but has the disadvantage of brittleness (Panfilov et al., 2008) and is also in shorter supply. Thus, platinum is the preferred alloy base among the PGMs in the most extreme environments in terms of elevated temperatures, aggressive atmospheres and higher stresses (Wolff and Hill, 2000; Hill et al., 2001a; Cornish et al., 2003). Concerning coatings on these alloys, investigations have indicated that either no coatings would be necessary, or at least simpler coatings could be used than those currently used on nickel-based superalloys (Cornish et al., 2009a, 2009b; Douglas et al., 2009). Three major ranges of Pt-based alloys have been developed. One is based on Pt-Al-Cr-Ni (Hüller et al., 2005; Wenderoth et al., 2005, 2007; Rudnik et al., 2008; Völkl et al., 2005, 2009) and two are based on Pt-Al-Cr-Ru (Cornish et al., 2009a, 2009b; Douglas et al., 2009). For the Pt-Al-Cr$\mathrm{Ru}$ alloys, one set was more malleable but less resistant to extreme chemical environments, whereas the other had higher chemical resistance, but was more difficult to form. The alloys showed very favourable mechanical properties (Süss et al., 2002). No alloys were produced commercially and the major problems was to identify a suitable application where the density of the alloys would not compromise their use, as they were too dense for the current designs of turbine engines. Another disadvantage is that they are extremely expensive. However, within these restrictions, the alloys could have potential as coatings on other lighter, more affordable substrates.

Under the Platinum Development Initiative (PDI), much work was done to prove the potential of a Pt-based alloy and some alloys were developed that showed very good properties (Cornish et al., 2003, 2009a, 2009b; Cornish and Chown, 2011; Douglas et al., 2009; Potgieter et al., 2010), which were mainly targeted for land-based turbines and were based on Pt-Al-Cr-Ru in South Africa, with German colleagues in the collaboration preferring to base their alloys on Pt-Al-Cr$\mathrm{Ni}$. The reason for their choice was a reluctance to use 


\section{PGMs: A cornucopia of possible applications}

ruthenium because of its ability to form $\mathrm{RuO}_{2}, \mathrm{RuO}_{4}$ and $\mathrm{RuO}_{3}$ (Caston, 1965) and it is the latter which has the highest partial vapour pressure, which was seen as a concern for long-term stability because of its volatility. The alloys performed well, but much better-supported parallel work outside of South Africa produced some lighter alloys which,.although they initially had stability problems, became better designed and were identified as having better potential in aerospace than the much denser Pt-based alloys, which would increase the momentum and hence the required strength in the moving parts of a turbine. Additionally, more work was done on the Ni-based superalloys which resulted in an increase the temperature range, although only by about $100^{\circ} \mathrm{C}$. Most of the improved temperature range was due to the improved coatings (which provide a thermal barrier), as well as the design of turbines which employ forced cooling. The Pt-based alloys did have better properties at higher temperatures than the Ni-based superalloys and the volime fraction of the precipitates was increased during the course of the research to become closer to that of the NBSAs (Shongwe et al., 2010). The PDI work also allowed collaboration with Cambridge University, UK (Fairbank et al., 2000; Hill et al., 2001a) and NIMS, Japan (Hill et al., 2001b). However, this work was changed to focus on coatings and some interesting coatings with potential were developed. The bulk alloys remain and could be used for applications where density is not a problem, possibly in reactors for high temperature and corrosive environments.

One of the interesting outomes from the work was the understanding of why there were two phase diagrams available for the base Pt-Al system (McAlister and Kahan, 1986; Oya et al., 1987). The diagrams differed in the shape of the platinum-based solid solution and well as the number and transformation temperatures of the $\mathrm{Pt}_{3} \mathrm{Al}$ phases. These differences were significant because they would affect the stabilities of the strengthening $\mathrm{Pt}_{3} \mathrm{Al}$ phases, as well as the amounts that could be produced. The German workers in the PDI collaboration (Fischer, 1992, 2001; Fischer et al. 1997 1999a, 1999b; Völkl et al., 2000; 2005, 2009; Hüller et al., 2005; Rudnik et al., 2008; Vorberg et al., 2004, 2005; Wenderoth et al., 2007) preferred McAlister and Kahan's (1986) diagram, while the South African workers preferred the McAlister and Kahan (1986) diagram for most of the phase boundaries, but Oya et al.'s (1987) diagram for the temperatures of transformation of the $\mathrm{Pt}_{3} \mathrm{Al}$ phases. The structure of one lower temperature phase was derived (Douglas et al., 2007) and showed some similarities to the modelled phase of Chauke et al. (2010). The only difference was the purity of the raw materials: those of the Germans were much purer (Cornish and Chown, 2011). This was an important observation, because the purity differences in the were small (less than 0.1 at.\%), but the affect was significant.

Later work (Odera et al., 2015) looked at reducing the Pt content without compromising the properties and substituted vanadium and/or niobium for some of the Pt, which could potentially increase the application temperature as well. An important outcome of this research was the development of a better method of etching the Pt-based alloys (Odera et al., 2012), which allowed the microstructure to be better resolved. This has improved the understanding of the microstructure-property relationship for different samples and has helped to determine the phase diagrams

Before the PDI work, Pt wires had been used to stabilize the position of components and Pt-Al coatings are used in the complex coatings of the nickel-based superalloys (Purvis and Warnes, 2001), because of their high temperature stability and strength. Some work continued on this using the experience derived from the bulk Pt-alloys.

\section{Shape memory alloys}

Shape memory alloys can change their shape at a specific temperature and are used in many applications: sensors, temperature-sensitive switches, force actuators, fire safety valves, orthodontic wires, fasteners and couplers. The most well-known example is NiTi, commercially known as Nitanol. Biggs et al. (2003) showed that the addition of platinum increases the transition temperature of the alloy, which would allow different applications. By varying the Pt content, the transition temperature for the shape memory alloy can be varied between room temperature and $1000^{\circ} \mathrm{C}$ and so alloys could be developed for niche applications at specific temperatures. There is potential for adding a ternary component to the $\mathrm{Pt}_{3} \mathrm{Al}$ and $\mathrm{PtTi}$ phases and the $\mathrm{PtFe}_{3}$ phase has been recognized for its potential for low temperature applications. Work has been done at Mintek, the University of the Witwatersrand and the CSIR, but no alloy has been commercialized yet from South Africa. It is likely that it would be better to identify the niche, derive the required properties and then select the most likely alloy.

PGM shape memory alloys could be used for dental applications, using the noble properties as well. In Germany, palladium is not permitted in dental alloys and so the target market must be assessed.

\section{Magnetic materials}

Magnetic materials are essential in many industries and there is a need to find substitutes for expensive rare earth metals. Historically, patents held by American and Japanese companies have been a barrier to entry to the magnet market, but China's establishment of research institutes in the 1950s and 1960s and the expiry of the American and Japanese patents in the 1980s, has enabled China to enter and dominate the magnet market. Currently, China has a monopoly on the magnet value chain, producing $90 \%$ of the world's permanent magnets. China also has most of the world's rare earth resources.

One of the new magnetic materials being investigated is the Fe-Co-Pd alloy, (Vokoun et al., 2005) which has potential applications in biotechnology, electronics and green technologies (hybrid vehicles and direct drive wind turbines). Magnetic thin films and nanostructures that are magnetized perpendicular to their surface are essential to many developing technologies, including spintronics devices (Mangin et al., 2006) and patterned media (Todorovic et al., 1999; Ding and Adeyeye, 2013), especially because of the need to maintain thermal stability as device dimensions are shrinking increasingly into the nanoscale. Multilayer or superlattice structures consisting of alternating ferromagnetic and non-magnetic layers are highly suitable for these applications due to their tunable perpendicular magnetic anisotropy (PMA) and saturation magnetization (Terris and Thomson, 2005; Rippard et al., 2010).

By combining the soft magnetic properties of iron and the 


\section{PGMs: A cornucopia of possible applications}

hard magnetic properties of cobalt and palladium, an optimal magnetic material could be developed (Vokoun et al., 2005). $\mathrm{Fe}-\mathrm{Co}$ alloys have a B2 structure which makes them extremely brittle at room temperature (Matsuda et al., 2016). The workability of this alloy can be improved by substitution of nickel or palladium. Substitution of palladium leads to a remarkably high tensile strength and elongation at room temperature (Matsuda et al., 2016).

Apart from the mechanical properties of the $\mathrm{Fe}-\mathrm{Co}-\mathrm{Pd}$ alloy and research on the magnetic shape memory properties, little work has been done on the ternary phase diagram. In order to understand the potential alloys better, the ternary phase diagram is needed, so that the compositions can be tailored to give the optimum phases for the desired properties.

\section{Conclusions}

The PGMs have a wide range of uses. Some of these are well established, but others are new. Although the PGMs show excellent properties, because of their high cost there is always the risk of substitution, even by materials with slightly inferior properties. However, there are newer potential uses and these should be targeted, first by research and then if successful, more commercially. The additions of small amounts of PGMs to other materials is worth pursuing and probably one of the most exciting applications are magnets containing $\mathrm{Pt}$ and $\mathrm{Pd}$.

\section{References}

Bard, J., Selman, G., Day, J., Bourne, A.A., Heywood A.E. and Benedek, R.A. 1994. Dispersion-strengthened materials - platinum-based alloys. Mechanical Properties of Metallic Composites. Ochiai, S. (ed.). Marcel Dekker, New York. pp. 341-371.

BIEFER, G.J. 1970. Effects of alloying on polarization and corrosion of type 430 stainless steel. Canadian Metallurgical Quarterly, vol. 9, no 4. 537 p.

Biggs, T., TAYLoR, S.S. and vAN DER Lingen, E. 2005. The hardening of platinum alloys for potential jewellery application. Platinum Metals Review, vol. 49, no. 1. pp. 2-15.

Biggs, T., Cortie, M.B., Witcomb, M.J. and Cornish, L.A. 2003. Platinum alloys for shape memory applications. Platinum Metals Review, vol. 47, no. 4. pp. $142-156$.

Chaston, J.C. 1965. Reactions of oxygen with the platinum metals. Platinum Metals Review, vol. 9, no. 2. pp. 51-57.

Chauke, H., Minisini, B., Drautz, R., Nguyen-Manh, D., Ngoepe, P. and Pettifor, D. 2010. Theoretical investigation of the Pt3Al ground state. Intermetallics, vol. 18. pp. 417-421.

CHernova, G.P. UstinskiI, E.N. and Tomashov, N.D. 1980. Self-passivation of plastic ruthenium-alloyed chromium in sulphuric acid solutions. Protection of Metals, vol. 16, no. 5. pp. 452-455.

CoRnish, L.A., FISCHER, B. and VöLKL, R. 2003. Development of platinum group metal based superalloys for high temperature use. Materials Research Bulletin, vol. 28, no. 9. pp. 632-638.

Cornish, L.A., Süss, R., Douglas, A., Chown, L.H. and Glaner, L. 2009a. The Platinum Development Initiative: platinum-based alloys for high temperature and special applications: Part I. Platinum Metals Review, vol. 53 , no. 1. pp. 2-10.

Cornish, L.A., Süss, R., Chown, L.H. and Glaner, L. 2009b. The Platinum Development Initiative: platinum-based alloys for high temperature and special applications: Part III. Platinum Metals Review, vol. 53, no. 3. pp. 155-163.

CoRnish, L.A. and Chown, L.H. 2011. Platinum-based alloys and coatings: materials for the future?, Advances in Gas Turbines. InTech. Chapter 15, pp. 337-370.

Coupland, D.R., Corti C.W and Selman, G.L. 1980. The PGM concept: enhanced resistant superalloys for industrial and aerospace applications. Behaviour of High Temperature Alloys in Aggressive Environments. Proceedings of of the Petten International Conference, Petten, The Netherlands, 15-18 October 1979. Kirman, I. (ed.). TMS, London.
Ding, J. and AdeyeYe, A.O. 2013. Binary ferromagnetic nano-structures: fabrication, static and dynamic properties. Advances in Functional Matererials, vol. 23. pp. 1684-1691.

Douglas, A., Neethling, J.H, Santamarta, R., Schryvers, D. and Cornish, L.A. 2007. Unexpected ordering behaviour of $\mathrm{Pt} 3 \mathrm{Al}$ intermetallic precipitates. Journal of Alloys and Compounds, vol. 432. pp. 96-102.

Douglas, A., Hill, P.J., Cornish, L.A. and Süss, R. 2009. The Platinum Development Initiative: Platinum-Based Alloys for High Temperature and Special Applications: Part II,. Platinum Metals Review, vol. 53, no. 2. pp. 69-77.

Fairbank, G.B., Humphreys, C.J., Kelly, A. and Jones, C.N. 2000. Ultra-high temperature intermetallics for the third millennium. Intermetallics, vol. 8, no. 9-11. pp. 1091-1100.

Fischer, B. 1992. Reduction of platinum corrosion in molten glass. Platinum Metals Review, vol. 36, no. 1. pp. 14-25.

FisCHER, B., Freund, D. and LuPTON, D.F. 1997. Stress-rupture strength and creep behaviour of platinum alloys. Precious Metals 1997, Proceedings of the IPMI 21st Annual Conference on Precious Metals, San Francisco, California, USA, 15-18 June 1997. International Precious Metals Institute, Pensacola, Florida. pp. 307-322.

Fischer, B., Behrends, A., Freund, D., LuPton D.F. and Merker, J. 1999a. Dispersion hardened platinum materials for extreme conditions. Proceedings of the 128th Annual Meeting and Exhibition of TMS, San Diego, California, 28 February-4 March 1999. pp. 321-331.

Fischer, B., Behrends, A., Freund, D., Lupton, D.F. and Merker, J. 1999b. High temperature mechanical properties of the platinum group metals. Platinum Metals Review, vol. 43, no. 1. pp. 18-28.

FischeR, B. 2001. New platinum materials for high temperature applications. Advanced Engineering Materials, vol. 3, no. 10. pp. 811-820.

GreENe, N.D., Bishop, C.R. and STERN, M.J. 1961. Corrosion and electrochemical behavior of chromium-noble metal alloys. Journal of the Elecctrochemical Society, vol. 108. pp. 836-841.

HAMmer, G. and KAufMAnN, D. 1982. Verfahren zur herstellung von halbzeugen aus dispersionsgehaertetem platin. German Patent 3,030,751 A1. Deguss AG.

HERAEUs. 2011). Dispersion hardened platinum materials. http://heraeusptcomponents.com/en/ downloads_1/technical_informations/publications_1/ [accessed 22 February 2011].

HeYwood, A.E. 1988. German Patent 3,102,342 C2. Johnson Matthey PLC.

Hill, P.J., Cornish, L.A. and Fairbank, G.B. 2001a. New developments in hightemperature platinum alloys. Journal of Metals, vol. 53, no. 10. pp. 19-20.

Hill, P.J., Yamabe-Mitarai, Y. And WolfF, I. 2001b. High-temperature compression strengths of precipitation-strengthened ternary Pt-Al-X alloys. Scripta Materialia, vol. 44, no. 1. pp. 43-48.

HoAR, T.P. 1960. Increasing the resistance to titanium to non-oxidising states. Platinum Metals Review, vol. 4, no. 2. pp. 59-64.

Huang, C., Yamabe-Miteral, Y. and Harada, H. 2004. The stabilization of $\mathrm{Pt}_{3} \mathrm{Al}$ phase with L12 structure in Pt-Al-Ir-Nb and Pt-Al-Nb alloys. Journal of Alloys and Compounds, vol. 366. pp. 217-221.

HÜller, M., Wenderoth, M., Vorberg, S., Fischer, B., Glatzel, U. and VöLKL, R. 2005. Optimization of composition and heat treatment of age-hardened Pt-Al-Cr-Ni alloys. Metallurgical and Materials Transactins A, vol. 36 , no. 13. pp. 681-689.

KNAPTon, A.G. 1977. Palladium alloys for hydrogen diffusion membranes: a review of high permeability materials. Platinum Metals Review, vol. 21 no. 2. pp. $44-50$

LuPTON, D.F. 1990. Noble and refractory metals for high temperature space applications. Advanced Materials. pp. 29-30.

Mangin, S., Ravelosona, D., Katine, J.A., Carey, M.J., Terris, B.D. and FULLERTON, E.E. 2006. Current-induced magnetization reversal in nanopillars with perpendicular anisotropy. Nature Materials, vol. 5. pp. 210-215.

Matsuda, M., Sago, R., AKamine, K., TsureKawa, S., TAKashima, K. and Nishida, M. 2016. Enhancement of ductility in Fe-Co based alloys by substitution of Pd. Journal of Alloys and Compounds, vol. 682. pp. 124-131.

McAlister, A.J. and KAHAN, D. J. 1986. The Al-Pt (aluminium-platinum) system, Bulletin of Alloy Phase Diagrams, vol. 7. pp. 45-51.

McGiLL, I.R. and LuCAS, K.A. 1987. Scratch-resistant platinum article. US Patent $4,828,933$.

MoNNARTZ, P. 1911. Iron-chromium alloys with special consideration of resistance to acids. Metallurgie (Halle), vol. 8, no. 7. pp. 161-176. 


\section{PGMs: A cornucopia of possible applications}

Odera, B.O., Cornish, L.A., PAPO, M.J. and RAding, G.O. 2012. Electrolytic etching of platinum-aluminium based alloys. Platinum Metals Review, vol. 56 , no. 4. pp. 257-261

Odera, B.O., Papo, M.J., Couperthwaite, R., Rading, G.O., Billing, D. and CoRnISH, L.A. 2015. High-order additions to platinum-based alloys for high temperature applications. Journal of the Southern African Institute of Mining and Metallurgy, vol. 115. pp. 241-250.

Olaseinde, O.A., van der Merwe, J.W., Cornish, L.A. and Olubambi, P.A. 2012. Electrochemical studies of $\mathrm{Fe}-21 \mathrm{Cr}-1 \mathrm{Ni}$ duplex stainless steels with $0.15 \mathrm{wt} \%$ ruthenium at different temperatures. Journal of the Southern African Institute of Mining and Metallurgy, vol. 112, no. 7. pp. 535-538.

OyA, Y., MishimA, U. and SuzuKI, T. 1987. L1 $2{ }_{2}$ DO $_{\mathrm{c}}$ martensitic transformation in $\mathrm{Pt}_{3} \mathrm{Al}$ and $\mathrm{Pt}_{3} \mathrm{Ga}$. Zeitschrift für Metallkunde, vol. 78, no. 7. pp. 485-490.

Panfilov, P., Pilugin, V.P. and Antonova, O.V. 2008. On specific feature of plastic deformation in Ir. Creep 2008: Proceedings of the 11th International Conference on Creep and Fracture of Engineering Materials and Structures, Bayreuth, Germany, 4-9 May. Abstract CP-131.

Potgieter, J.H., Heynes, A.M. and Skinner, W. 1990. Cathodic modification as a means improving the corrosion resistance of alloys. Journal of Applied Electrochemistry, vol. 20. pp. 711-715.

PotGiETER, J.H. 1991 Alloys cathodically modified with noble metals. Journal of Applied Electrochemistry, vol. 21. pp. 471-482.

Potgieter, J.H., van Bennekom, A. and Ellis, P. 1995. Investigation of the active dissolution behaviour of a $22 \%$ chromium duplex stainless steel with small ruthenium additions in sulphuric acid. ISIJ International, vol. 35. pp. 197-202.

Potgieter, J.H., Maledi, N.B., SePhton, M. and Cornish, L.A. 2010. The Platinum Development Initiative: platinum-based alloys for high temperature and special applications: Part IV - Corrosion. Platinum Metals Review, vol. 54, no. 2. pp. 112-119.

Purvis, A.L. and WARnEs, B. M. 2001. The effects of platinum concentration on oxidation resistance of superalloys coated with single-phase platinum aluminide. Surface and Coatings Technology, vol. 146. pp. 1-6.

Rippard, W.H., Deac, A.M., Pufall, M.R., Shaw, J.M., Keller, M.W., Russek, S.E., BAUerand, G.E.W. and SeRPico, C. 2010. Spin-transfer dynamics in spin valves with out-of-plane magnetized CoNi free layers. Physical Reviews B. $81 \mathrm{p}$.

RudNiK, Y., VöLKL, R., Vorberg, S. and GlatZel, U. 2008. The effects of Ta additions on the phase compositions and high temperature properties of $\mathrm{P}$ base alloys. Materials Science and Engineering A, vol. 479. pp. 306-312.

Shing, T.L., Luyckx, S., NoRThrop, I.T. and WolfF, I. 2001. The effect of ruthenium additions on the hardness, toughness and grain size of WC-Co. International Journal of Refractory Metals and Hard Materials, vol. 19. pp. 41-44.

Shongwe, M.B., Odera, B., Samal, S., Ukpong, A.M., Watson, A., Süss, R., Chown, L.H., RAding, G.O. and CoRnish, L.A. 2010. Assessment of microstructures in the development of Pt-based superalloys. Proceedings of Light Metals 2010, Muldersdrift, Johannesburg, 27-29 October 2010. Southern African Institute of Mining and Metallurgy, Johannesburg. pp. 184-202.

Stern, M. and Wissenberg, H. 1959. The influence of noble metal alloy additions on the electrochemical and corrosion behaviour of titanium. Journal of the Electrochemical Society, vol. 106, no. 9. pp. 759-764.

STREICHER, M.A. 1977. Alloying stainless steels with the platinum metals. Platinum Metals Review, vol. 21. pp. 51-54.

Süss, R., Freund, D., VölKL, R., Fischer, B., Hill, P.J., Ellis, P. and WolfF, I.M 2002. The creep properties of Pt-base $\gamma /$ ' analogues to Ni-base superalloys. MaterialsScience and Engeering A, vol. 338. pp. 133-141.

TerRIS, B.D. and THomson, T. 2005. Nano fabricated and self-assembled magnetic structures as data storage media. Journal of Physics, vol. D38 pp. 199-222.

Todorovic, M., Schultz, S., Wong, J. and Scherer, A. 1999. Writing and reading of single magnetic domain per bit perpendicular patterned media. Applied Physics Letters, vol. 74. pp. 2516-2518.

Tomashov, N.D. 1958. Methods of increasing the corrosion resistance of metal alloys. Corrosion, vol. 40. 229t.

Tomashov, N.D. 1967. Passivity and Protection of Metals Against Corrosion. 2nd edn. Springer. 83 p.

Tomashov, N.D., Chernova, G.P. and Utrinski, E.N. 1969. Platinum Metals Review, vol. 23, no. 4. pp. 143-149.

Tomashov, N.D. Chernova, G.P. and VolKov, L.N. 1970. Effect of palladium on corrosion and electrochemical behaviour of OKH25N6T steel. Zaschita Metallov, vol. 6, no. 4. pp. 425-427.
TOMASHOV, N.D. ,KaZARIN, V.I. MiKheEv, V.S. and GonchaRENKo, B.A. 1976. Effect of ruthenium on the electrochemical and corrosion behaviour of titanium and titanium-nickel alloys in acid chloride solutions. Protection of Metals, vol. 12, no. 5. pp. 471-474.

TomASHov, N.D. 1980. Study of the potential oscillations of the alloys on the basis of chromium alloyed with the metals of the platinum group on solutions of sulphuric acid. Physical Chemistry Chemical Physics, vol. 84, no. 4. pp. 383-387.

Tomashov, N.D., Chernova, G.P. and Ustinsky, E.N. 1984. Effect of platinum elements additions on the active dissolution of plastic chromium in sulfuric acid. Corrosion, vol. 40, no. 3. pp. 134-137.

VAN DER Lingen, E. and SANDENBERGH, R.F. 2001. The cathodic modification behaviour of $\mathrm{Ru}$ additions to titanium in hydrochloric acid. Journal of Corrosion Science, vol. 43. pp. 577-590.

Voкоun, D., WANG, Y.W., GoRyczkA, T. and Hu, C.T. 2005. Magnetostrictive and shape memory properties of Fe-Pd alloys with $\mathrm{Co}$ and Pt additions. Smart Materials and Structures, vol. 14, no. 5. S261 p.

VöLkL, R., Freund, D., Behrends, A., Fischer, B., Merker, J. and Lupton, D. 2000. Platinum base alloys for high temperature space applications. Euromat 99 Series: Materials for Transport. Winkler, P.J. (ed.). Wiley-VCH, Weinheim.

VöLKL, R., YAmabe-Mitarai, Y., Huang, C. and Harada, H. 2005. Stabilizing the L12 structure of $\mathrm{Pt} 3 \mathrm{Al}(\mathrm{r})$ in the Pt-Al-Sc system. Metallurgical and Materials Transactions A, vol. 36, no. 11. pp. 2881-2892.

VöLkL, R., Wenderoth, M., Preussner, J., Vorberg, S., Fischer, B., YamabeMiterai, Y., Harada, H. and Glatzel, U. 2009. Development of a precipitation-strengthened Pt-base alloy. Materials Science and Engineering A, vol. 510-511. pp. 328-331.

Vorberg, S., Wenderoth, M., Fischer, B., Glatzel, U. and VölKL, R. 2004. Pt-AlCr-Ni superalloys: heat treatment and microstructure. Journal of Metals vol. 56, no. 9. pp. 40-43.

Vorberg, S., Wenderoth, M., Fischer, B., Glatzel, U. and VöLKL, R. 2005. A TEM investigationof the $\gamma /$ ' phase boundary in Pt-based superalloys. Journal of Metals, vol. 57, no. 3. pp. 49-51.

Weber, W., Zimmermann, K. and Beyer, H.H. 1996. Surface-hardened objects of platinum and palladium and their method of production. US Patent $5,518,556$

Wenderoth, M., VölkL, R., Vorberg, S., Yamabe-Miterai, Y., Harada, H. and GLATZEL, U. 2007. Microstructure, oxidation resistance and high temperature strength of $\gamma /$ ' hardened Pt base alloys. Intermetallics, vol. 15. pp. 539-549.

Wenderoth, M., Cornish, L.A., Süss, R. Vorberg, S., Fischer, B., Glatzel, U. \& Völki, R. (2005). On the Development and Investigation of Quaternary PtBased Superalloys with Ni Additions. Metallurgical and Materials Transactions, A, vol. 36 p.

Whalen, M.V. 1988. Space station resistojets. Platinum Metals Review, vol. 32 , no. 1. pp. 2-10.

WolfF, I.M. and HiLl, P.J. 2000. Platinum metals-based intermetallics for hightemperature service. Platinum Metals Review, vol. 44, no. 4. pp. 158-166.

Yamabe, Y., Koizumi, Y., Murakami, H., Ro, Y., Maruko, T. and Harada, H. 1996. Development of Ir-base refractory superalloys. Scripta Meterialia, vol. 35, no. 2. pp. 211-215.

Yamabe-Mitarai, Y., Koizumi, Y., Murakami, H., Ro, Y., Maruko, T. and Harada, H. 1997. Rh-base refractory superalloys for ultra-high temperature use Scripta Meterialia, vol. 36, no. 4. pp. 393-398.

YAmabe-Mitarai, Y., Ro, Y., Harada, H. and Maruko, T. 1998a. Ir-base refractory superalloys for ultra-high temperature use. Metallurgical Transactions A, vol. 29, no. 2. pp. 537-549.

Yamabe-Mitarai, Y., Ro, Y., Maruko, T. and Harada, H. 1998b. Precipitation hardening of Ir-Nb and Ir-Zr alloys. Scripta Materialia, vol. 40, no. 1. pp. 109-115.

Yamabe-Mitarai, Y., Ro, Y., Maruko, T. and Harada, H. 1999. Microstructure dependence of strength of Ir-base refractory superalloys. Intermetallics, vol. 7 , no. 1. pp. 49-58.

YAMABE-MitARA, Y. and AoKI, H. 2003. An assessment of Pt-Ir-Al alloys for high temperature materials. Journal of Alloys and Compounds, vol. 59. pp. 143-152.

Yu, X.H., Yamabe-MitaraI, Y., Ro, Y. and Harada, H. 2000. Design of quaternary Ir-Nb-Ni-Al refractory superalloys. Metallurgical and Materials Transactions A, vol. 31A, no. 1. pp. 173-178A.

Zhang, L., Zhang, W., Jiang, Y., Deng, B., Sun, D. and Li, J. 2009. Influence of annealing treatment on the corrosion resistance of lean duplex stainless steel 2101. Electrochimica Acta, vol. 54, no. 23. pp. 5387-5392. 